\title{
Ion specificity in determining physico-chemical properties of drinking water
}

\author{
Domenico PREZIOSO ${ }^{1}$, Dante DI DOMENICO ${ }^{1}$, Manuela PANE${ }^{1}$, Donato CICCARELLI ${ }^{2}$, Gerardino D’ERRICO ${ }^{2 *}$
}

\begin{abstract}
Drinking water plays a key role in regulating the daily salt intake, thus potentially affecting (either in positive or in negative direction) the incidence of diet-related pathologies, including nephrolithiasis. Being regarded as wholesome, bottled water is increasingly preferred to tap water. However, its physico-chemical characterization, as reported on the label, is usually limited to $\mathrm{pH}$ and conductivity measurements, along with ion content. Other parameters, which also are likely to influence the processes in which water is involved in the body, are usually neglected. In this work, the surface tension and density of tap water and two bottled mineral waters produced in Italy are investigated. These parameters are critically determined by the ion content. Density is connected to the total ion amount, while surface tension is differentially affected by the presence of specific ions: sulfate increases its value, while bicarbonate keeps it almost constant. These results furnish a reliable scientific basis for future investigation on the connection between the physico-chemical properties of drinking water and its effect on health. Particularly, since interfacial phenomena play a key role in kidney stone formation, our results suggest that dietary enrichment of selected ions due to water intake could affect nephrolithiasis.
\end{abstract}

Keywords: bottled mineral water; labeling; surface tension; density; ion content.

Practical Application: This paper highlights the importance of implementing analytical tests on tap water as well as on bottled mineral waters. Parameters different from those routinely reported on the labels could be important in determining the water effect on the human health. These parameters depend in different way on the ion content. A deeper investigation on these points, joined to a wide dissemination of the results is essential to drive a correct choice of water to be drunk from the consumer to optimize the beneficial effects.

\section{Introduction}

Diet is considered to be a major risk factor for idiopathic calcium stone formation (Robertson, 2016; Prezioso et al., 2015), and is likely responsible for nephrolithiasis growing incidence in the last decades. Preventing recurrent urolithiasis, by adopting correct dietary habits, could lead to a significant cost savings for the national health care systems (Lotan et al., 2013). Many dietary factors have been implicated in this disease, including an insufficient fluid intake (Robertson, 1987), high or low intakes of calcium (Curhan et al., 1993), high intakes of oxalate (Robertson \& Peacock, 1980) and sodium (Massey \& Whiting, 1995), low intakes of magnesium (Reungjui et al., 2002) and potassium (Domrongkitchaiporn et al., 2006). As a matter of fact, drinking water plays a key role in regulating all these factors. Water effect is further enhanced by the fact that for all nephrolithiasis patients, regardless of the underlying cause of the disease, a keystone of conservative management is an increased water intake to achieve a daily urine output of two liters (Borghi et al., 1999; Frank \& Vries, 1966). Indeed, patients prefer a change in the quantity water intake to another dietary or pharmaceutical intervention to contrast the high probability of recurrence of nephrolithiasis (Hughes, 2007; Trinchieri et al., 2000). Moreover, they pay particular attention to the quality of drinking water (McCauley et al., 2012).
Many people are now preferring bottled water to tap water. By 2016, bottled water volume achieved a new record, exceeding 48 billion liters, almost 15 billion liters higher than it had been in 2007 (Rodwan, 2017). Worldwide, there are thousands of companies bottling water. The impressive increase in bottled water consumption has to be ascribed to i.) consumers' apprehension over attaining safe and accessible drinking water; ii.) consumers' complaints about tastes and odors from municipal water due to additives such as fluoride or chlorine; iii.) manufacturers' advertising of bottled water as "pure" water, perfectly suited to kids and old people; and last, but not least, iv.) consumers' conviction that natural mineral waters exert beneficial, and even therapeutic, effects on human health (Salehi et al., 2014; Semerjian, 2011; Güler \& Alpaslan, 2009; Ward et al., 2009). With respect to the last point, the connection with nephrolithiasis would appear obvious. Physico-chemical parameters of drinking water, and particularly hardness, fixed residue and ions concentration, are expected to impact on the risk of renal stones. In the case of bottled water, all these parameters are by law listed on the label, and significantly drive the consumer choice (Kermanshahi et al., 2010).

${ }^{1}$ Dipartimento di Neuroscienze e Scienze Riproduttive ed Odontostomatologiche, Università degli Studi di Napoli "Federico II", Napoli, Italia

${ }^{2}$ Dipartimento di Scienze Chimiche, Università degli Studi di Napoli “Federico II”, Complesso Universitario di Monte Sant'Angelo, Napoli, Italia

*Corresponding author: gerardino.derrico@unina.it 
From the scientific viewpoint, drinking water quality has been demonstrated to affect urine characteristics, including $\mathrm{pH}$, the ratio of calcium crystal formation initiators and inhibitors, the concentration of ions (Schwartz et al., 2002). In turn, these play a fundamental role in regulating the processes leading to the formation of stones in the kidneys and urinary tract (Evan et al., 2015; Coe et al., 2010). On this basis, the relationship between nephrolithiasis and water physico-chemical features is object of active current research (Rabi et al., 2013). Most of the studies focus on the total quantity of dissolved electrolyte in drinking water (Bellizzi et al., 1999; Chatterjee et al., 2012) or, more specifically, on the effects of distinct electrolytes (Panhwar et al., 2013; Siener et al., 2004). Despite the researchers efforts, the effect of water hardness on nephrolithiasis remains unclear (Schwartz et al., 2002; Coen et al., 2001; Rodgers, 1997); on the other hand, it is now generally accepted that bicarbonate-rich water have a positive effect (Karagülle et al., 2007; Bertaccini \& Borghesi, 2009), probably due to increased $\mathrm{pH}$ which increases solubility of uric acid and urinary citrate concentration, with inhibition of calcium crystal formation and aggregation. The presence of other solutes, such as humous (humic and fulvic) acids, has also been analyzed and connected with the degradation of stones in the urinary tract (Davydova et al., 2014). In contrast, analysis of collective physico-chemical parameters of water is usually limited to electrical conductivity and $\mathrm{pH}$ measurements (Siener et al., 2004). Investigation on other parameters is missing.

The nucleation and growth of stone-forming minerals is related to the interfacial energy between the liquid (urine) and the solid (the growing stone) (Wu et al., 1999; Russo et al., 2015). In turn, the interfacial energy is determined by the surface tension of the two phases put in contact (Marmur \& Valal, 2010; Muñoz-García et al., 2015). The liquid surface tension is determined by the solutes content that is related to diet (Paßlack et al., 2014) and, especially in a regime of increased water intake, to drinking water (Toxqui \& Vaquero, 2016; Schwartz et al., 2002). Thus, surface tension of drinking water is likely to be related to nephrolithiasis. However, scientific investigation on this specific parameter is missing.

In the present work, we present surface tension data (IUPAC symbol: $\gamma$ ) collected on tap water as well as on two bottled mineral waters commercially available in Italy. One of these, Acqua Rocchetta, has been reported to exert a significant detoxicant activity on the body (Paolo et al., 2000), and hypothesized to be beneficial in preventing nephrolithiasis. The other mineral water, chosen as a reference, presents very similar solid residue, thus allowing the relevance of the different salt composition (at almost constant total amount) to be highlighted. Moreover, to complement the surface tension data, we report density data (IUPAC symbol: $\rho$ ) acquired on the same samples.

\section{Materials and methods}

\subsection{Water sampling}

Tap water was sampled in Piazza Dante, a square in center of Napoli (Italia), in July 2017. Two brands of mineral water were considered. The former one is Acqua Rocchetta (whose spring is located in Gualdo Tadino, in central Italy); the latter one has been chosen to allow a comparison and, in the following sections, will be indicated as Reference Mineral Water. The physico-chemical parameters of tap water, as reported on the official website of the local public water supplier (ABC - Acqua Bene Comune) and those of the two mineral waters, reported on the labels as required from the current legislation (Council of the European Union, 1980), are shown in Table 1.

A total of 10 water bottles for each considered brand were purchased in spring 2017 at 10 different supermarkets throughout the city of Napoli (Italia). The bottles, with a capacity of 0.5 liters, were made of PET (polyethylene terephthalate) and had a PE (polyethylene) screw cap. From each bottle, four water samples were analyzed by tensiometry and densimetry, and each measurement was repeated in triplicate.

\subsection{Surface tension measurements}

Surface tension measurements were performed using apparatus and procedures described in details in previous studies (Ortona et al., 2006). Briefly, the surface tension, $\gamma$, was measured by the De Nouy ring method using a KSV Sigma 70 digital tensiometer equipped with an automatic device to set the time between two consecutive measurements and to select the rising velocity of the platinum ring. Mineral water samples were put in the tensiometer circular vessel, thermostatted at $25.00 \pm 0.01^{\circ} \mathrm{C}$. Instrument accuracy was checked to be better

Table 1. Physicochemical parameters reported on the official website of the neapolitan public water supplier $\mathrm{ABC}$ (Acqua Bene Comune) for tap water and on labels of the investigated bottled mineral waters.

\begin{tabular}{lccc}
\hline & Tap Water & $\begin{array}{c}\text { Acqua } \\
\text { Rocchetta }\end{array}$ & $\begin{array}{c}\text { Reference } \\
\text { Mineral } \\
\text { Water }\end{array}$ \\
\hline $\begin{array}{l}\text { Solid Residue at } \\
180^{\circ} \mathrm{C} /(\mathrm{mg} / \mathrm{L})^{\mathrm{a}}\end{array}$ & 536 & 174.1 & 162 \\
$\begin{array}{l}\text { Specific Electric } \\
\text { conductivity at }\end{array}$ & 765 & 276.3 & 251 \\
$20^{\circ} \mathrm{C} /(\mu \mathrm{S} / \mathrm{cm})^{\mathrm{b}}$ & & & \\
$\mathrm{pH}^{\text {at the spring }}$ & 7.4 & 7.56 & 7.9 \\
temperature & 126.0 & 57.36 & 35.9 \\
$\mathrm{Ca}^{++} /(\mathrm{mg} / \mathrm{L})$ & 35 & 4.13 & 2.0 \\
$\mathrm{Na}^{+}$ & 31.3 & 3.23 & 12.6 \\
$\mathrm{Mg}^{++}$ & 17.5 & 0.35 & 0.5 \\
$\mathrm{~K}^{+}$ & not reported & 0.23 & not reported \\
$\mathrm{Sr}^{++}$ & 503 & 182.1 & 148 \\
$\mathrm{HCO}_{3}^{-}$ & 55 & 6.75 & 19.3 \\
$\mathrm{SO}_{4}^{-}$ & 50 & 6.78 & 2.4 \\
$\mathrm{Cl}^{-}$ & 31 & 1.10 & 4.4 \\
$\mathrm{NO}_{3}^{-}$ & 0.69 & 0.13 & not reported \\
$\mathrm{F}^{-}$ & not reported & 4.17 & not reported \\
$\mathrm{SiO}_{2}$ & 0.03 & not reported & $<0.002$ \\
$\mathrm{NO}_{2}^{-}$ & & & \\
\hline & & & \\
\hline
\end{tabular}

aThis value represents the mass of inorganic and organic substances that remains after complete evaporation of one liter of water at $180^{\circ} \mathrm{C}$, according to the Italian D. Lgs. $31 / 2001$ (Italy, 2001); ${ }^{b}$ The specific electric conductivity of ultrapure water is $0.055 \mu \mathrm{S} / \mathrm{cm}$. 
than $0.10 \mathrm{mN} \mathrm{m}^{-1}$ by measuring $\gamma$ for double distilled and degassed water (surface tension of ultra-pure water at $25^{\circ} \mathrm{C}$ is $71.97 \mathrm{mN} \mathrm{m}^{-1}$ ) before and after each session of measurements.

\subsection{Density measurements}

Density measurements were performed using apparatus and procedures described in details in previous studies (Molisso et al., 2010; Vergara et al., 2002; Ambrosone et al., 1997). Briefly, densities, $\rho$, of water samples were determined with an Anton Paar DMA5000 density meter at the temperature $(25.000 \pm 0.005){ }^{\circ} \mathrm{C}$, using double distilled water and air at known pressure and humidity as references. According to the specifications declared for this instrument the repeatability is equal to $10^{-6} \mathrm{~g} \cdot \mathrm{cm}^{-3}$.

\subsection{Statistical treatment of data}

The statistical analyses were performed using the Graph-Pad Prism version 7.00 (GraphPad Software). D'Agostino and Pearson normality test was performed and groups showing normal distribution were analyzed by the t-test, while groups showing not-normal distribution were analyzed by Mann-Whitney $\mathrm{U}$ test; two-tailed $\mathrm{P}<0.05$ was chosen as significance threshold.

\section{Results and discussion}

Experimental surface tension data are shown in Figure 1. The average values are summarized in Table 2. Tap water presents a surface tension, $\gamma$, higher than that of double distilled and degassed water $\left(72.40 \mathrm{mN} \mathrm{m}^{-1}\right.$ vs. $\left.71.97 \mathrm{mN} \mathrm{m}^{-1}\right)$. The datum obtained for Acqua Rocchetta $\left(72.04 \pm 0.08 \mathrm{mN} \mathrm{m}^{-1}\right)$ coincides, within the experimental uncertainty, with that of double distilled

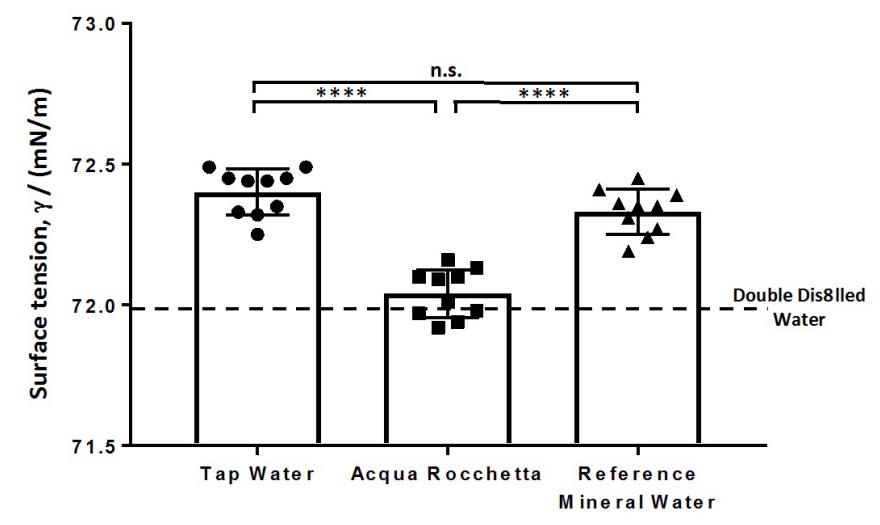

Figure 1. Surface tension, $\gamma$, of tap water and bottled mineral waters at $25^{\circ} \mathrm{C}$. Bars represent the mean value \pm standard deviation $\left({ }^{* * * *} \mathrm{P}<0.0001\right.$; n.s. means no significant difference). water. The datum obtained for the Reference Mineral Water $\left(72.33 \pm 0.09 \mathrm{mN} \mathrm{m}^{-1}\right)$ is similar to that observed for tap water.

It is interesting to analyze these data on the basis of the salt contents reported in Table 1. As a general consideration, the presence of inorganic salts increases the surface tension of aqueous mixtures (Chen et al., 2017). This is interpreted considering that ions tend to be surrounded by hydrating water molecules, thus avoiding residing at the air/water interface; this means that fewer ions are found at the interface than in the water bulk. As a consequence, the interface tends to shrink, and this results in an increase of the surface tension (Dutcher et al., 2010). This is confirmed by the values obtained for tap water and for the Reference Mineral Water, showing values higher than that of double distilled and degassed water (see Table 2). One could expect surface tension to positively correlate with solid residue values. Indeed, the solid residue which remains after complete evaporation of one liter of water at $180^{\circ} \mathrm{C}$ is mostly constituted by inorganic salts, see Table 1 , so that it can be considered a coarse index of the ion content in the considered water samples. Similar considerations hold for the electric conductivity, which also is a measure of dissolved electrolytes. However, the positive correlation is not confirmed by our results: Acqua Rocchetta, which has a similar (slightly higher, indeed) solid residue and specific electric conductivity values with respect to the Reference Mineral Water and, overall, a higher salt content (see Table 1), presents a lower surface tension. Thus, our data show that the surface tension is affected by the presence and amount of specific ions rather than their total amount. Perusal of Table 1 reveals that: i) concerning the cations, Acqua Rocchetta presents a high content of sodium and calcium while the magnesium content is low; ii) concerning the anions, Acqua Rocchetta presents a high content of bicarbonate and a low content of sulfate.

Magnesium and sulfate are among the most "structure makers" ions (kosmotropes), considered to be able to induce ordering in water beyond their hydration shells (Tobias \& Hemminger, 2008), while large singly charged ions, with low charge density, such as bicarbonate, act as "structure breakers" (chaotropes) (Du et al., 2008). Kosmotropes prefer to reside in the bulk water, where ordered structures can be fully formed in all directions. This driving force is much minor for chaotropes, which can remain at the interface, thus being much less effective in increasing the solution surface tension. This interpretation is fully in line with our experimental evidences.

Experimental density data are shown in Figure 2. The average values are summarized in Table 2. Tap water present a density $\left(0.997877 \mathrm{~g} / \mathrm{cm}^{3}\right)$ higher than that of double distilled water $\left(0.997045 \mathrm{~g} / \mathrm{cm}^{3}\right)$. The datum obtained for Acqua Rocchetta $\left(0.997294 \mathrm{~g} / \mathrm{cm}^{3}\right)$ is only slightly different from the datum obtained for the Reference Mineral Water $\left(0.997274 \mathrm{~g} / \mathrm{cm}^{3}\right)$ and

Table 2. Surface tension, $\gamma$, and density, $\rho$, of the investigated tap and mineral waters at $25^{\circ} \mathrm{C}$.

\begin{tabular}{lcccc}
\hline & $\begin{array}{c}\text { Degassed and Doubly } \\
\text { Distilled Water }\end{array}$ & Tap Water & Acqua Rocchetta & Reference Mineral Water \\
\hline Surface tension, $\gamma /(\mathrm{mN} / \mathrm{m})$ & $71.97^{\mathrm{a}}$ & $72.40 \pm 0.08$ & $72.04 \pm 0.08$ & $72.33 \pm 0.09$ \\
Density, $\rho /\left(\mathrm{g} / \mathrm{cm}^{3}\right)$ & $0.997045^{\mathrm{b}}$ & $0.997877 \pm 0.000005$ & $0.997294 \pm 0.000008$ & $0.997274 \pm 0.000005$ \\
\hline${ }^{a}$ From Ortona et al. (2006); ${ }^{\text {b } F r o m ~ A m b r o s o n e ~ e t ~ a l . ~(1996) . ~}$ & &
\end{tabular}

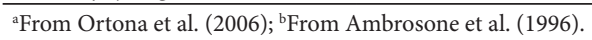




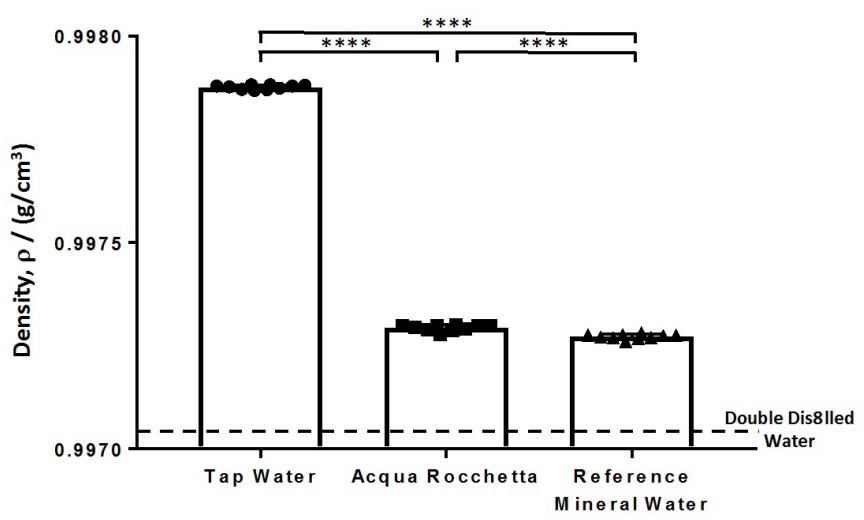

Figure 2. Density, $\rho$, of tap water and bottled mineral waters at $25^{\circ} \mathrm{C}$. Bars represent the mean value \pm standard deviation $\left({ }^{* * *} \mathrm{P}<0.0001\right)$.

both of them are significantly higher than the density of double distilled and degassed water.

Even in this case, the experimental evidences can be related to the ion content. When a salt is dissolved in water, the solution density usually increases. This evidence is ascribed to the electrostriction phenomenon: under the electric field exerted by ions, the hydrogen bonds between water molecules break down leading to a molecular crowding and a diminution of the void spaces (Marcus, 2011). Inspection of Table 1 shows that the density increment well correlates with the solid residue and the specific electric conductivity of the investigated samples. Tap water, whose solid residue is much higher than those of bottled waters, presents a much higher density. In the same manner, similar densities correspond to similar solid residue values, the slightly higher density observed for Acqua Rocchetta being in line with its solid residue which slightly higher than that of the Reference Mineral Water. Thus, it seems that the ions total amount is the fundamental properties in regulating the density of mineral water; specific effects exerted by selected ions, reported in the literature (Mazzini \& Craig, 2017), play a minor role.

\section{Conclusions}

Studies concerning nephrolithiasis disease distribution demonstrate that, besides a specific genetic predisposition, environmental factors, and specifically dietary habits, are important (Miller et al., 2007). A correct nutritional management of stone formers patients is effective in preventing or at least delaying kidney stones formation and recurrence, thus reducing the need of drugs and the consequent risks of intolerance and side effects (Prezioso et al., 2015). Particularly, the quantity and quality of drinking water seems to plays a relevant role in contrasting nephrolithiasis. However, the water characteristics that determine this beneficial effect remain poorly understood.

In the present study we investigated the surface tension and density of two bottled mineral waters with similar solid residue. We found similar density values, indicating that this property is mainly regulated by the total amount of ions. Interestingly, this is not true for surface tension: one of the water brands presents a value very close to that of neat water, while a significant surface tension increase is observed for the other one. This evidence has been interpreted in terms of the different ions present in the two mineral waters. Particularly, we propose sulfate and magnesium to cause a surface tension increase. At the molecular level, this could be connected to the effect of ions on the structure of water, which is related to the subtle balance between ion-water and water-water interactions. Tap water, whose ion content is much higher with respect to those of the considered bottled waters, present both higher density and higher surface tension.

As a general conclusion of our work, it is to be remarked that, among the various features of drinking water, the importance of solubilized ions cannot be overstated. Beyond their total amount, the specific nature is vital in controlling a wealth of physical, chemical and biological properties. The ion specificity in driving a given physico-chemical phenomenon in aqueous solution is largely variable: some phenomena seem to nonspecifically depend on the total ionic strength, while others are only induced by selected ions. In these cases, the order of ions effectiveness is hardly predictable (Imperatore et al., 2014). Our results demonstrate that the surface tension of water depends on the presence of specific ions. Being interfacial phenomena fundamental in crystal growth underlying kidney stone formation, it can be reasonably speculated that enrichment of urine in selected ions due to water intake could affect nephrolithiasis.

Although far from conclusive, this study shows that small variations in ions content and composition could significantly affect physico-chemical properties of drinking water. The extent to which this variation reflects in the healthy effect of a given mineral water brand remains to be established. In this respect, surface tension is a perfect candidate to be further investigated as a key property to be related to the insurgence of nephrolithiasis.

\section{References}

Ambrosone, L., Costantino, L., D’Errico, G., \& Vitagliano, V. (1996). Density and viscosity studies of poly(ethylene-oxide) alkyl alcohols. Journal of Solution Chemistry, 25(8), 757-772. http://dx.doi. org/10.1007/BF00973783.

Ambrosone, L., Costantino, L., D’Errico, G., \& Vitagliano, V. (1997). Thermodynamic and dynamic properties of micellar aggregates of nonionic surfactants with short hydrophobic tails. Journal of Colloid and Interface Science, 190(2), 286-293. http://dx.doi.org/10.1006/ jcis.1997.4860. PMid:9241168.

Bellizzi, V., De Nicola, L., Minutolo, R., Russo, D., Cianciaruso, B., Andreucci, M., Conte, G., \& Andreucci, V. E. (1999). Effects of water hardness on urinary risk factors for kidney stones in patients with idiopathic nephrolithiasis. Nephron, 81(Suppl. 1), 66-70. http:// dx.doi.org/10.1159/000046301. PMid:9873217.

Bertaccini, A., \& Borghesi, M. (2009). Indications for a medium mineral high bicarbonate water (Cerelia) in urology. Archivio Italiano di Urologia, Andrologia, 81(3), 192-194. PMid:19911684.

Borghi, L., Meschi, T., Schianchi, T., Briganti, A., Guerra, A., Allegri, F., \& Novarini, A. (1999). Urine volume: Stone risk factor and preventive measure. Nephron, 81(Suppl. 1), 31-37. http://dx.doi. org/10.1159/000046296. PMid:9873212.

Chatterjee, D., Verma, V., Amiti, Rohil, S., Raj, N. A. N., \& Vidya, R. (2012). Demographic study of water hardness with potential to predict formation of renal crystals. Advanced Materials Research, 584, 504508. http://dx.doi.org/10.4028/www.scientific.net/AMR.584.504. 
Chen, H., Li, Z., Wang, F., Wang, Z., \& Li, H. (2017). Investigation of surface properties for electrolyte solutions: measurement and prediction of surface tension for aqueous concentrated electrolyte solutions. Journal of Chemical \& Engineering Data, 62(11), 37833792. http://dx.doi.org/10.1021/acs.jced.7b00503.

Coe, F. L., Evan, A. P., Worcester, E. M., \& Lingeman, J. E. (2010). Three pathways for human kidney stone formation. Urological Research, 38(3), 147-160. http://dx.doi.org/10.1007/s00240-010-0271-8. PMid:20411383.

Coen, G., Sardella, D., Barbera, G., Ferrannini, M., Comegna, C., Ferazzoli, F., Dinnella, A., D’Anello, E., \& Simeoni, P. (2001). Urinary composition and lithogenic risk in normal subjects following oligomineral versus bicarbonate-alkaline high calcium mineral water intake. Urologia Internationalis, 67(1), 49-53. http://dx.doi. org/10.1159/000050944. PMid:11464116.

Council of the European Union. (1980). Council directive of 15 July 1980 on the approximation of the laws of the Member States relating to the exploitation and marketing of natural mineral waters (80/777/ EEC). Bruxelles: Official Journal of the European Communities.

Curhan, G. C., Willett, W. C., Rimm, E. B., \& Stampfer, M. J. (1993). A prospective study of dietary calcium and other nutrients and the risk of symptomatic kidney stones. The New England Journal of Medicine, 328(12), 833-838. http://dx.doi.org/10.1056/NEJM199303253281203. PMid:8441427.

Davydova, N. K., Sergeev, V. N., \& Girbul, E. (2014). The role of humous acids in Acqua di Fiuggi mineral water in degrading stones formed in the urinary tract. Pharmaceutical Chemistry Journal, 48(9), 589594. http://dx.doi.org/10.1007/s11094-014-1155-y.

Domrongkitchaiporn, S., Stitchantrakul, W., \& Kochakarn, W. (2006). Causes of hypocitraturia in recurrent calcium stone formers: focusing on urinary potassium excretion. American Journal of Kidney Diseases, 48(4), 546-554. http://dx.doi.org/10.1053/j.ajkd.2006.06.008. PMid:16997050.

Du, H., Liu, J., Ozdemir, O., Nguyen, A. V., \& Miller, J. D. (2008). Molecular features of the air/carbonate solution interface. Journal of Colloid and Interface Science, 318(2), 271-277. http://dx.doi. org/10.1016/j.jcis.2007.09.097. PMid:18035369.

Dutcher, C. S., Wexler, A. S., \& Clegg, S. L. (2010). Surface tensions of inorganic multicomponent aqueous electrolyte solutions and melts. The Journal of Physical Chemistry A, 114(46), 12216-12230. http:// dx.doi.org/10.1021/jp105191z. PMid:21043484.

Evan, A. P., Worcester, E. M., Coe, F. L., Williams, J. Jr., \& Lingeman, J. E. (2015). Mechanisms of human kidney stone formation. Urolithiasis, 43(Suppl. 1), 19-32. http://dx.doi.org/10.1007/s00240-014-0701-0. PMid:25108546.

Frank, M., \& Vries, A. (1966). Prevention of urolithiasis: education to adequate fluid intake in a new town situated in the Judean Desert Mountains. Archives of Environmental Health, 13(5), 625-630. http:// dx.doi.org/10.1080/00039896.1966.10664630. PMid:5925636.

Güler, C., \& Alpaslan, M. (2009). Mineral content of 70 bottled water brands sold on the Turkish market: assessment of their compliance with current regulations. Journal of Food Composition and Analysis, 22(7-8), 728-737. http://dx.doi.org/10.1016/j.jfca.2009.03.004.

Hughes, P. (2007). The CARI guidelines: kidney stones epidemiology - caring for Australians with renal impairment (CARI). Nephrology (Carlton, Vic.), 12(Suppl. 1), 26-30. http://dx.doi.org/10.1111/j.14401797.2006.00724.x.

Imperatore, R., Vitiello, G., Ciccarelli, D., \& D’Errico, G. (2014). Effects of salts on the micellization of a short-tailed nonionic ethoxylated surfactant: an intradiffusion study. Journal of Solution Chemistry, 43(1), 227-239. http://dx.doi.org/10.1007/s10953-014-0133-z.
Italy, Governo della Repubblica. (2001, March 3). Decreto Legislativo 2 febbraio 2001, n. 31. Attuazione della direttiva 98/83/CE relativa alla qualita' delle acque destinate al consumo umano. Gazzetta Ufficiale, n. 52, supplemento Ordinario n. 41.

Karagülle, O., Smorag, U., Candir, F., Gundermann, G., Jonas, U., Becker, A. J., Gehrke, A., \& Gutenbrunner, C. (2007). Clinical study on the effect of mineral waters containing bicarbonate on the risk of urinary stone formation in patients with multiple episodes of CaOx-urolithiasis. World Journal of Urology, 25(3), 315-323. http:// dx.doi.org/10.1007/s00345-007-0144-0. PMid:17333204.

Kermanshahi, K. Y, Tabaraki, R., Karimi, H., Nikorazm, M., \& Abbasi, S. (2010). Classification of Iranian bottled waters as indicated by manufacturer's labellings. Food Chemistry, 120(4), 1218-1223. http:// dx.doi.org/10.1016/j.foodchem.2009.11.067.

Lotan, Y., Buendia Jiménez, I., Lenoir-Wijnkoop, I., Daudon, M., Molinier, L., Tack, I., \& Nuijten, M. J. C. (2013). Increased water intake as a prevention strategy for recurrent urolithiasis: major impact of compliance on cost-effectiveness. The Journal of Urology, 189(3), 935-939. http://dx.doi.org/10.1016/j.juro.2012.08.254. PMid:23017509.

Marcus, Y. (2011). Electrostriction in electrolyte solutions. Chemical Reviews, 111(4), 2761-2783. http://dx.doi.org/10.1021/cr100130d. PMid:21319739.

Marmur, A., \& Valal, D. (2010). Correlating interfacial tensions with surface tensions: a Gibbsian approach. Langmuir, 26(8), 5568-5575. http://dx.doi.org/10.1021/la9038478. PMid:20055369.

Massey, L. K., \& Whiting, S. J. (1995). Dietary salt, urinary calcium and kidney stone risk. Nutrition Reviews, 53(5), 131-139. http://dx.doi. org/10.1111/j.1753-4887.1995.tb01536.x. PMid:7666985.

Mazzini, V., \& Craig, V. S. J. (2017). What is the fundamental ionspecific series for anions and cations? Ion specificity in standard partial molar volumes of electrolytes and electrostriction in water and non-aqueous solvents. Chemical Science, 8(10), 7052-7065. http://dx.doi.org/10.1039/C7SC02691A. PMid:29147533.

McCauley, L. R., Dyer, A. J., Stern, K., Hicks, T., \& Nguyen, M. M. (2012). Factors influencing fluid intake behavior among kidney stone formers. The Journal of Urology, 187(4), 1282-1286. http:// dx.doi.org/10.1016/j.juro.2011.11.111. PMid:22341296.

Miller, N. L., Evan, A. P., \& Lingeman, J. E. (2007). Pathogenesis of renal calculi. The Urologic Clinics of North America, 34(3), 295-313. http:// dx.doi.org/10.1016/j.ucl.2007.05.007. PMid:17678981.

Molisso, A., Mangiapia, G., D’Errico, G., \& Sartorio, R. (2010). Interaction of poly(vinyl alcohol) with poly(acrylic acid) and with sodium polyacrylate in aqueous solutions: a volumetric study at 25 ${ }^{\circ}$ C. Journal of Solution Chemistry, 39(11), 1627-1635. http://dx.doi. org/10.1007/s10953-010-9615-9.

Muñoz-García, A. B., Sannino, F., Vitiello, G., Pirozzi, D., Minieri, L., Aronne, A., Pernice, P., Pavone, M., \& D’Errico, G. (2015). Origin and electronic features of reactive oxygen species at hybrid zirconiaacetylacetonate interfaces. ACS Applied Materials \& Interfaces, 7(39), 21662-21667. http://dx.doi.org/10.1021/acsami.5b06988. PMid:26394654.

Ortona, O., D’Errico, G., Paduano, L., \& Vitagliano, V. (2006). Interaction between cationic, anionic, and non-ionic surfactants with ABA block copolymer Pluronic PE6200 and with BAB reverse block copolymer Pluronic 25R4. Journal of Colloid and Interface Science, 301(1), 6377. http://dx.doi.org/10.1016/j.jcis.2006.04.041. PMid:16777133.

Panhwar, A. H., Kazi, T. G., Afridi, H. I., Shaikh, H. R., Arain, S. A., Arain, S. S., \& Brahman, K. D. (2013). Evaluation of calcium and magnesium in scalp hair samples of population consuming different drinking water: risk of kidney stone. Biological Trace Element 
Research, 156(1-3), 67-73. http://dx.doi.org/10.1007/s12011-0139850-1. PMid:24218227.

Paolo, N., Sassone, D., Cappelletti, F., Rossi, P., \& Garosi, G. (2000). Azione detossicante dell'acqua minerale Rocchetta. Giornale di Tecniche Nefrologiche \& Dialitiche, 12(4), 19-26.

Paßlack, N., Burmeier, H., Brenten, T., Neumann, K., \& Zentek, J. (2014). Short term effects of increasing dietary salt concentrations on urine composition in healthy cats. Veterinary journal (London, England: 1997), 201(3), 401-405. http://dx.doi.org/10.1016/j.tvjl.2014.04.015. PMid:24881513.

Prezioso, D., Strazzullo, P., Lotti, T., Bianchi, G., Borghi, L., Caione, P., Carini, M., Caudarella, R., Ferraro, M., Gambaro, G., Gelosa, M., Guttilla, A., Illiano, E., Martino, M., Meschi, T., Messa, P., Miano, R., Napodano, G., Nouvenne, A., Rendina, D., Rocco, F., Rosa, M., Sanseverino, R., Salerno, A., Spatafora, S., Tasca, A., Ticinesi, A., Travaglini, F., Trinchieri, A., Vespasiani, G., \& Zattoni, F. (2015). Dietary treatment of urinary risk factors for renal stone formation. A review of CLU Working Group. Archivio Italiano di Urologia, Andrologia, 87(2), 105-120. http://dx.doi.org/10.4081/aiua.2015.2.105. PMid:26150027.

Rabi, S., Mbarki, M., \& Oussama, A. (2013). In vitro study of the effect of the quality of drinking water on the crystallization of calcium oxalate and uric acid. Physical and Chemical News, 69, 61-66.

Reungjui, S., Prasongwatana, V., Premgamone, A., Tosukhowong, P., Jirakulsomchok, S., \& Sriboonlue, P. (2002). Magnesium status of patients with renal stones and its effect on urinary citrate excretion. BJU International, 90(7), 635-639. http://dx.doi.org/10.1046/j.1464410X.2002.03015.x. PMid:12410738.

Robertson, W. G. (1987). Diet and calcium stones. Mineral and Electrolyte Metabolism, 13(4), 228-234. PMid:3306314.

Robertson, W. G. (2016). Dietary recommendations and treatment of patients with recurrent idiopathic calcium stone disease. Urolithiasis, 44(1), 9-26. http://dx.doi.org/10.1007/s00240-0150849-2. PMid:26645870.

Robertson, W. G., \& Peacock, M. (1980). The cause of idiopathic calcium stone disease: hypercalciuria or hyperoxaluria? Nephron, 26(3), 105-110. http://dx.doi.org/10.1159/000181963. PMid:7412965.

Rodgers, A. L. (1997). Effect of mineral water containing calcium and magnesium on calcium oxalate urolithiasis risk factors. Urologia Internationalis, 58(2), 93-99. http://dx.doi.org/10.1159/000282958. PMid:9096270.

Rodwan, J. G. (2017). Bottled water 2016: no. 1 and growing: US and international developments and statistics. Bottled Water Reporter, 57(4), 12-21.
Russo, V., Tesser, R., Trifuoggi, M., Giugni, M., \& Di Serio, M. (2015). A dynamic intraparticle model for fluid-solid adsorption kinetics. Computers \& Chemical Engineering, 74(1), 66-74. http://dx.doi. org/10.1016/j.compchemeng.2015.01.001.

Salehi, I., Ghiasi, M., Rahmani, A. R., Sepehr, M. N., Kiamanesh, M., \& Rafati, L. (2014). Evaluation of microbial and physico-chemical quality of bottled water produced in Hamadan province of Iran. Journal of Food Quality and Hazards Control, 1(1), 21-24.

Schwartz, B. F., Schenkman, N. S., Bruce, J. E., Leslie, S. W., \& Stoller, M. L. (2002). Calcium nephrolithiasis: effect of water hardness on urinary electrolytes. Urology, 60(1), 23-27. http://dx.doi.org/10.1016/ S0090-4295(02)01631-X. PMid:12100915.

Semerjian, L. A. (2011). Quality assessment of various bottled waters marketed in Lebanon. Environmental Monitoring and Assessment, 172(1-4), 275-285. http://dx.doi.org/10.1007/s10661-010-1333-7. PMid:20148363.

Siener, R., Jahnen, A., \& Hesse, A. (2004). Influence of a mineral water rich in calcium, magnesium and bicarbonate on urine composition and the risk of calcium oxalate crystallization. European Journal of Clinical Nutrition, 58(2), 270-276. http://dx.doi.org/10.1038/ sj.ejcn.1601778. PMid:14749747.

Tobias, D. J., \& Hemminger, J. C. (2008). Getting specific about specific ion effects. Science, 319(5867), 1197-1198. http://dx.doi.org/10.1126/ science.1152799. PMid:18309069.

Toxqui, L., \& Vaquero, M. P. (2016). An intervention with mineral water decreases cardiometabolic risk biomarkers. A crossover, randomised, controlled trial with two mineral waters in moderately hypercholesterolaemic adults. Nutrients, 8(7), 400. http://dx.doi. org/10.3390/nu8070400. PMid:27367723.

Trinchieri, A., Coppi, F., Montanari, E., Nero, A., Zanetti, G., \& Pisani, E. (2000). Increase in the prevalence of symptomatic upper urinary tract stones during the last ten years. European Urology, 37(1), 23-25. http://dx.doi.org/10.1159/000020094. PMid:10671780.

Vergara, A., Paduano, L., \& Sartorio, R. (2002). Mechanism of protein - Poly(ethylene glycol) interaction from a diffusive point of view. Macromolecules, 35(4), 1389-1398. http://dx.doi.org/10.1021/ ma011390s.

Ward, L. A., Cain, O. L., Mullally, R. A., Holliday, K. S., Wernham, A. G. H., Baillie, P. D., \& Greenfield, S. M. (2009). Health beliefs about bottled water: a qualitative study. BMC Public Health, 9(1), 196. http://dx.doi.org/10.1186/1471-2458-9-196. PMid:19545357.

Wu, W., Gerard, D. E., \& Nancollas, G. H. (1999). Nucleation at surfaces: the importance of interfacial energy. Journal of the American Society of Nephrology, 10(Suppl. 14), S355-S358. PMid:10541263. 